\title{
PEACE AGREEMENT BETWEEN \\ THE GOVERNMENT OF THE REPUBLIC OF RWANDA AND THE RWANDESE PATRIOTIC FRONT
}

The Government of the Republic of Rwanda on the one hand, and the Rwandese Patriotic Front on the other;

Firmly resolved to find a political negotiated solution to the war situation confronting the Rwandese people since 1st October, 1990;

Considering and appreciating the efforts deployed by the countries of the Sub-region with a view to helping the Rwandese people to recover peace;

Referring to the numerous high-level meetings held respectively at Mwanza United Republic of Tanzania, on 17th October, 1990, in Gbadolite, Republic of Zaire, on 26th October, 1990, in Goma, Republic of Zaire, on 20th November, 1990, in Zanzibar, United Republic of Tanzania, on 17th February, 1991, in Dar-esSalaam, United Republic of Tanzania, on 19th February, 1991and from 5th to 7 March, 1993;

Considering that all these meetings aimed first and foremost at establishing a ceasefire so as to enable the two parties to look for a solution to the war through direct negotiations;

Noting the N'SELE Ceasefire Agreement, of 29th March, 1991 as amended in GBADOLITE on 16th Septernber,1991 and at ARUSHA on 12th July, 1992;
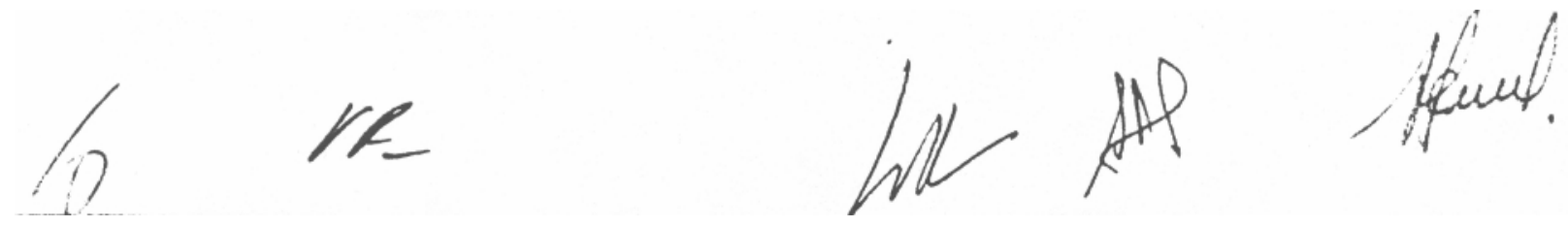
Reaffirming their unwavering determination to respect principles underlying the Rule of Law which include democracy, national unity, pluralism, the respect of fundamental freedoms and rights of the individual;

Considering that these principles constitute the basis and consistency of a lasting peace awaited by the Rwandese people for the benefit of the present and future generations;

Noting the Protocol of Agreement on the Rule of Law signed at Arusha on $18^{\text {th }}$ August, 1992;

Considering that the two parties accepted the principle of power-sharing within the framework of a Broad-Based Transitional Government;

Noting the Protocols of Agreement on Power-Sharing signed at ARUSHA respectively on 30th October, 1992, and on 9th January, 1993;

Considering that the conflictual situation between the two parties can only be brought to an end through the formation of one and single National Army and a new National Gendarmerie from forces of the two warring parties;

Noting of the Protocol of Agreement on the integration of Armed Forces of both Parties, signed at Arusha on 3rd August, 1993;

Recognizing that the unity of the Rwandese people cannot be achieved until a definitive solution to the problem of Rwandese refugees is found and that the return of Rwandese refugees to their country is an inalienable right and constitutes a factor for peace and national unity and reconciliation;

Noting the Protocol of Agreement on the repatriation of Rwandese refugees and the Resettlement of Displaced Persons, signed at ARUSHA on 9th June, 1993;
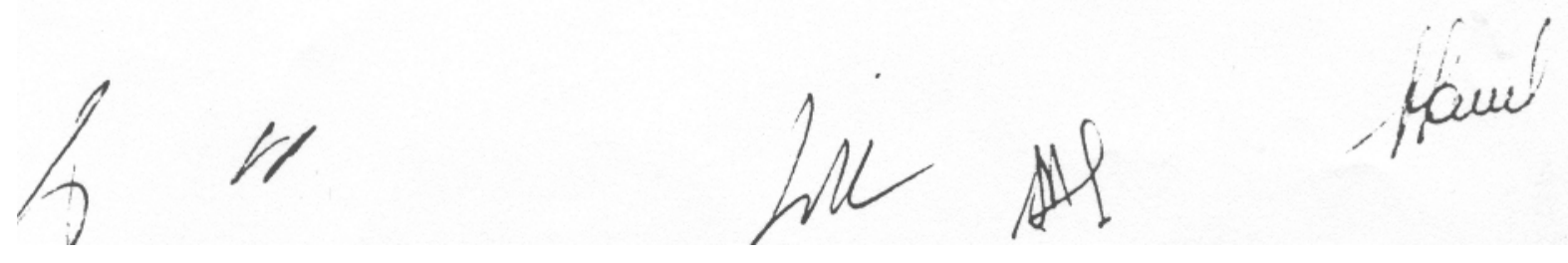
Resolved to eradicate and put a definite end to all the root causes which gave rise to the war;

Have, at the conclusion of the Peace Talks held in Arusha, United Republic of Tanzania, between 10th July, 1992 and 24th June, 1993 as well as Kinihira, Republic of Rwanda from 19th to 25th July, 1993 under the aegis of the Facilitator, His Excellency Ali Hassan MWINYI, President of the United Republic of Tanzania, in the presence of the Representative of the Mediator, His Excellency, MOBUTU SESESEKO, President of the Republic of Zaire as well as Representatives of the Current Chairmen of the OAU, His Excellency Abdou DIOUF, President of the Republic of Senegal, and Hosni MUBARAK, President of the Arab Republic of Egypt, the Secretary General of the OAU, Dr. Salim Ahmed SALIM, the Secretary General of the United Nations, Dr. Boutros Boutros GHALI and Observers representing the Federal Republic of Germany, Belgium, Burundi, the United States of America, France, Nigeria, Uganda and Zimbabwe;

Calling the International Community to witness;

Hereby agree on the following provisions.

Article 1: The war between the Government of the Republic of Rwanda and the Rwandese Patriotic Front is hereby brought to an end.

Article 2: The following documents are an integral part of the present Peace Agreement concluded between the Government of the Republic of Rwanda and the Rwandese Patriotic Front:

I. The N'SELE Ceasefire Agreement of 29th March, 1991 between the Government of the Republic of Rwanda and the Rwandese Patriotic Front, as amanded in GBADOLITE on 16th September, 1991 and at ARUSHA or.2th July, 1992;
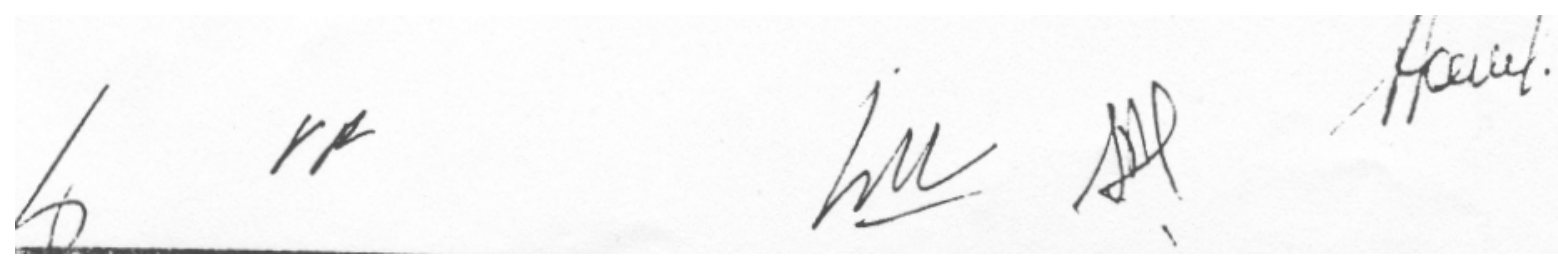
II. The Protocol of Agreement between the Government of the Republic of Rwanda and the Rwandese Patriotic Front on the Rule of Law, signed at ARUSHA on 18th September, 1992;

III. The Protocols of Agreement between the Government of the Republic of Rwanda and the Rwandese Patriotic Front on Power-Sharing within the Framework of a Broad-Based Transitional Government, signed at ARUSHA respectively on 30th October, 1992 and on 9th January, 1993;

IV. The Protocol of Agreement between the Government of the Republic of Rwanda and the Rwandese Patriotic Front on the Repatriation of Refugees and the Resettlement of Displaced Persons, signed at Arusha on 9th June, 1993;

V. The Protocol Agreement between the Government of the Republic of Rwanda and the Rwandese Patriotic Front on the integration of Armed Forces of the two parties, signed at ARUSHA on, 3rd August 1993;

VI. The Protocol of Agreement between the Government of the Republic of Rwanda and the Rwandese Patriotic Front on Miscellaneous Issues and Final Provisions signed at Arusha on 3rd August, 1993.

These entire documents are attached as Annex.

Article 3: The two parties also agree that the Constitution of 10th June, 1991 and the Arusha Peace Agreement shall constitute indissolubly the Fundamental Law. that shall govern the Country during the Transition period, taking in to account the following provisions:
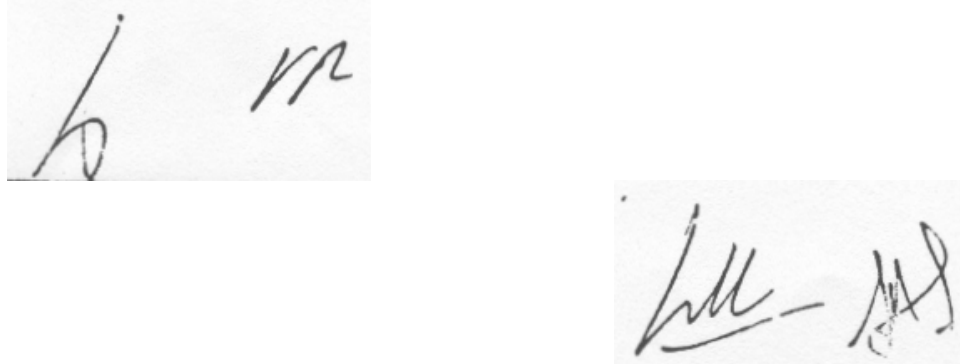
1. The following articles of the Constitution shall be replaced by the provisions of the Peace Agreement relating to the same matters. The Articles in question are: $34,35,38,39,40,41,42,43,44,45,46,47,48,49,50,51,52,54,55$, $56,57,58,59,60,63,65,66,67,68,70,71,73,74,75$ paragraph 2,77 paragraphs 3 and $4,81,82,83,84,85,86,87,88$ paragraph 1, 90, 96, 99,101.:

2 In case of conflict between the other provisions of the Constitution and those of the Peace Agreement, the provisions of the Peace Agreement shall prevail.

3. The Constitutional Court shall verify the conformity of Laws and Orders in Council with the Fundamental Law thus defined. Pending the enactment of the law on the Supreme Court, the existing Constitutional Court shall remain composed of both the Court of Cassation and the State of Council. The Presiding Judge of the Constitutional Court shall assume the presidency.

Article 4: In case of conflict between the provisions of the Fundamental Law and those of other Laws and Regulations, the provisions of the Fundamental Law shall prevail.

Article 5: The Government of the Republic of Rwanda and the Rwandese Patriotic Front undertake to make every possible effort to ensure that the present Peace Agreement is respected and implemented.

They further undertake to spare no effort to promote National Unity an Reconciliation.
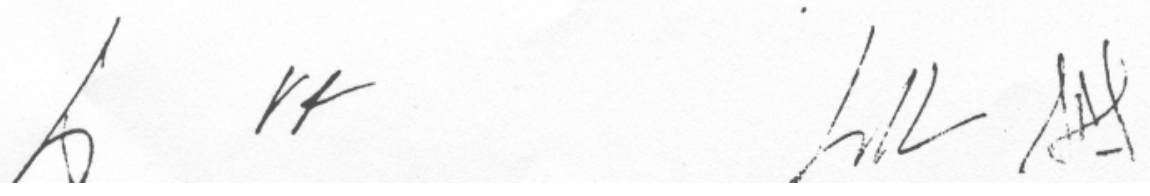
Article 6: The two parties agree on the appointment of Mr. TWAGIRAMUNGU Faustin as Prime Minister of the Broad-Based Transitional Government, in accordance with Articles 6 and 51 of the Protocol of Agreement between the' Government of the Republic of Rwanda and the Rwandese Patriotic Front on Power-Sharing within the framework of a Broad-Based Transitional Government.

Article 7: The Transitional Institutions shall be set up within thirty seven (37) days following the signing of the Peace Agreement.

Article 8: The current Government shall remain in Office until the Broad-Based. Transitional Government is established. The maintenance of that Government does not mean that it can encroach on the mandate of the Broad-Based Transitional Government being established.

The current Government shall, in no case, take decisions which may be detrimental to the implementation of the Broad-Based Transitional programme.

Article 9; The "Conseil National de Developpment" (CND) shall remain in Office until the Transitional National Assembly is established. However, as from the date of signing the Peace Agreement, it shall not enact laws.

Article 10: The present Peace Agreement is signed by the President of the Republic of Rwanda and the Chairman of the Rwandese Patriotic Front, in the presence of:

The Facilitator, His Excellency, Ali Hassan MWINYI, President of the United Republic of Tanzania,

His Excellency, Yoweri Kaguta MUSEVENI, President of the Republic of Uganda; Observer country;
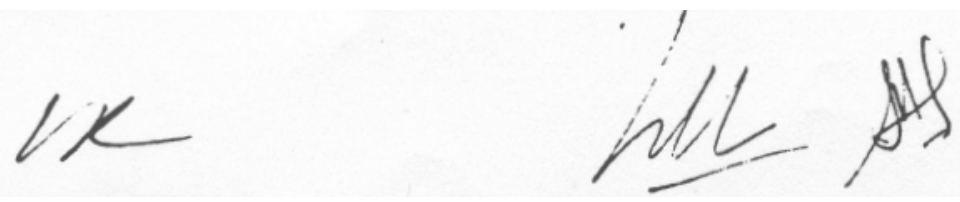
- $\quad$ His Excellency Melchior NDADAYE, President of the Republic of Burundi, Observer country;

- $\quad$ The Representative of the Mediator, His Excellency Faustin BIRINDWA, Prime Minister of Zaire;

- $\quad$ Dr. Salim Ahmed SALIM, Secretary General of the OAU;

- $\quad$ The Repesentative of the Secretary General of the United Nations;

- $\quad$ The Representative of the Current Chairman of the OAU;

- $\quad$ The Representatives of other Observer countries: Germany, Belgium, United States of America, France, Nigeria and Zimbabwe;

The delegations of the two parties.

Article 11: The present Peace Agreement shall come into force upon its signing by the parties.

Done at Arusha, on the 4th day of the month of August, 1993 both in French and English languages, the original text being in French. 


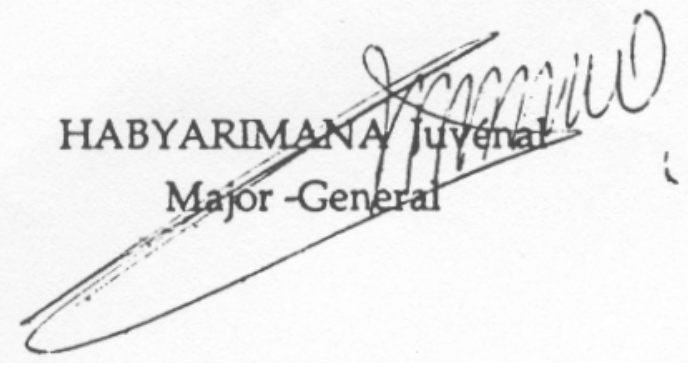

President of the Republic of Rwanda

\section{KANYARENGWE AleXis \\ Colonel}

Chairman of the Rwandese Patriotic Front

In the presence of the Facilitator

Ali Hassan MWINYI

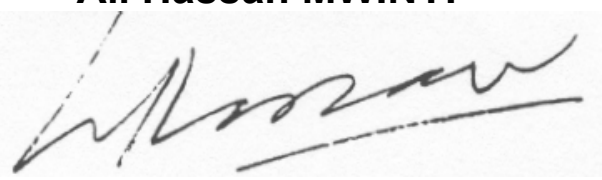

President of the United Republic of Tanzania

In the presence of the Representative of In the presence of the Secretary General of the Secretary General of the United the OAU

Nations

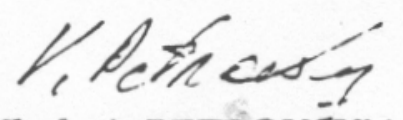

Mr. Vladmir PETROVSKY

Under-Secretary General

Director General of the United Nations

Office at Geneva

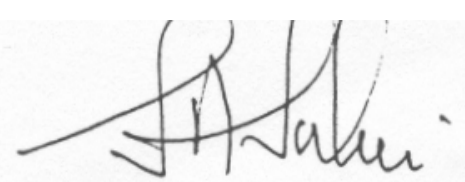

Dr. Salim Ahmed SALIM 